\title{
GIS Site Selection Model for Sanitary Landfill Based on Geotechnical Parameters
}

\author{
Dr. Digant Pastagia ${ }^{1}$, Dr. Kamal Padhiyar ${ }^{2}$
}

${ }^{1}$ Assistant Professor, CED, Shree Swami Atmanand Saraswati Institute of Technology, Surat, Gujarat, India

${ }^{2}$ Assistant Professor, CED, RNGPIT, Bardoli, Gujarat, India

\begin{abstract}
Solid waste disposal area is a function of many parameters. Geo-technical parameters are very important, since they are often connected to the surrounding open ground. In addition, secure and appropriate land that is usable is also scarce. Geo-technical parameters are also used in this document to establish a GIS model to determine a suitable location for landfill purposes. Surat Metropolitan City is India's most densely populated and fastest growing urban area. The research goals are to perform field experiments to collect data and move the facts to find an optimal position in the GIS platform to evolve a model. The expectations of planners were collected in order to find weights for each parameter using the analytical hierarchical method (AHP). In order to improve decision-making, GIS integration and Multi-Criteria Decision Analysis (MCDA) techniques are applied. It increases an atmosphere for transformation and mixing of geographical data and preferences of planners. Deterministic overlay and buffer operations are carried out by GIS. MCDA approaches test alternatives based on the individual beliefs and preferences of the decision makers. Many alternative sites have been illustrated by study findings. Economic analysis of the chosen site from the point of view of real activities is not included in this report.
\end{abstract}

Keywords : Urbanization, Municipal Solid Waste, GIS, Geotechnical parameters, analytical hierarchy process, landfill

\section{INTRODUCTION}

In India, Municipal Solid Waste has created several geological imbalances. Unfortunately, geotechnical as well as socio-economic variables are scarcely quantified and places of disposal are assumed to be determined. Taking into account India's situation, an approach focused on GIS analysis is proposed. The urban population of India is rising globally at the fastest pace. It is therefore difficult to combat urban problems and the pattern of scientific development. For the disposal of municipal solid waste, where geotechnical safe landfill site selection is important, a scientific decision-making approach needs to be adopted. In order to find an optimal place to make choices, GIS has taken the MCDA approach. To test parametric weights, the Analytic Hierarchy Method (AHP) is used. In India, the city under study is the fastest growing urban center.

\subsection{STUDY AREA}

For this research work, which is a major industrial hub and the fastest growth centre, Surat city is selected. Surat(Gujarat, India) is situated in western India's coastal region. The city is located at $72.83^{\circ} \mathrm{E}$, $21.17^{\circ} \mathrm{N}$. Surat is India's fourth fastest growing city 
and is the business capital of the state of Gujarat. The total area of the city is 326.56 square kilometres. The City has primary potential in the form of the Tapi River. There are CBD (Old City) and Non-CBD (New City) regions in the city. The city is governed by the Surat Municipal Corporation, the state government (SMC). SUDA is preparing the growth and urban planning programs, i.e. Community Planning Authority of Surat. In the form of highways, railways and air transport, the city is well connected with others. Surat is second largest city in Gujarat and ninth largest in India.

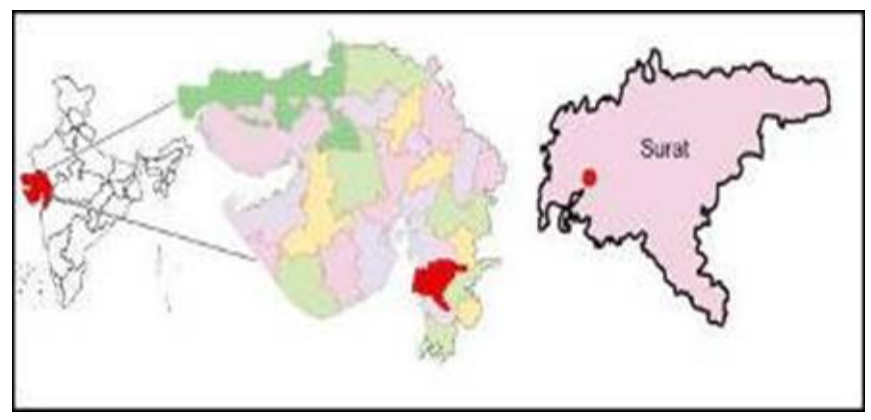

Figure 1.0 Location map of Surat

Surat produces 400 gms of waste per capita per day, amounting to around 1000 metric tons. This is obtained by SMC, the rag pickers and private contractors. Households, stores and other commercial establishments contribute about 70 percent of the waste produced each day. There is recyclability for just over 30 percent of the total waste produced. This consists mainly of paper, plastic, metal, brick and glass Combustible waste accounts for 22.75 percent of the total and almost 42 percent is organic waste. In Surat, refining and disposal techniques such as incineration etc. are not used. The sanitary landfill cell is produced and the cell is ready for use for the disposal of inert material collected at the end of the MSW Treatment treatment process.

MSW was dumped into open space at Bhatar prior to the MSW-2000 rules. Surat Municipal Corporation has been established according to MSW-2000 regulations. A sanitary landfill site in the 200-hectare district of Khajod. For inert residues, an area of 1.25 lac cu.m is under construction and a sanitary landfill site with a capacity of 6.25 lac cu.m is ready for use.

\subsection{STUDY OBJECTIVES}

Following are the research objectives:

- Evaluating geotechnical criteria that affect the selection of solid waste landfill sites.

- To assess the weight by AHP of each parameter.

- Using the GIS MCDA technique to determine an optimal location for landfill sites.

\section{SITING METHODOLOGY}

Landfill site selection is a dynamic planning of land use with various parameters that should convince all relevant stakeholders with distinct insights. The approach to landfill location is focused on opposing views among experts in planning. The problem was studied from multiple points of view in order to achieve optimized siting decisions. The first phase was based on the sampling of opinions and the findings of questionnaires by 15 experts familiar with local circumstances, national planning laws and foreign practices. The result was analyzed in SPSS software using these opinions of all the experts to verify the validity of the parameters and less important parameters were discarded and five geotechnical parameters were considered for the analysis at the end.

In the next stage, data on all five parameters was collected and a GIS database was created in the form of base maps in Arc GIS 10.0.0.0. In the third level, the standardization of criteria and weighting of criteria was done using AHP (Analytical Hierarchical Process), which was also based on the opinion of experts. 
Table 1: Geotechnical parameters used and its description

\begin{tabular}{|c|c|c|}
\hline Sr. No. & $\begin{array}{c}\text { Geotechnical } \\
\text { Parameters }\end{array}$ & Description \\
\hline 1 & Soil permeability & $\begin{array}{c}\text { To understand its } \\
\text { seepage capacity } \\
\text { through in it }\end{array}$ \\
\hline 2 & Soil density & $\begin{array}{c}\text { It is the ratio of } \\
\text { weight to volume } \\
\text { to identify } \\
\text { whether it is loose } \\
\text { or dense }\end{array}$ \\
\hline 3 & Atterberg limits & $\begin{array}{c}\text { To identify soil } \\
\text { property of } \\
\text { plasticity and non- } \\
\text { plasticity }\end{array}$ \\
\hline 4 & Moisture content & $\begin{array}{c}\text { To know degree of } \\
\text { saturation of soil } \\
\text { mass }\end{array}$ \\
\hline 5 & Specific gravity & $\begin{array}{c}\text { To understand } \\
\text { void ratio of soil } \\
\text { mass }\end{array}$ \\
\hline
\end{tabular}

The suitability maps for landfill locations in Surat, India, were then evaluated according to planning visions using a pair wise comparison process. In the fourth point, after crossing three resulting maps with different visions, the final suitability map was obtained and documented in five suitability groups for landfill construction.

\subsection{DATA COLLECTION AND ANALYSIS}

Soil samples are obtained from twenty eight different locations and analyzed. Five soil sample parameters were checked, as shown in Table 1. The final suitability map was prepared on the basis of these five criteria. As far as the geological state of the soil is concerned, the final suitability map shows the best locations for landfill construction. For this analysis, the soil sample positions are demonstrated in this chart below. In order to obtain soil quality charts, sample positions are seen outside the study region for interpolation.

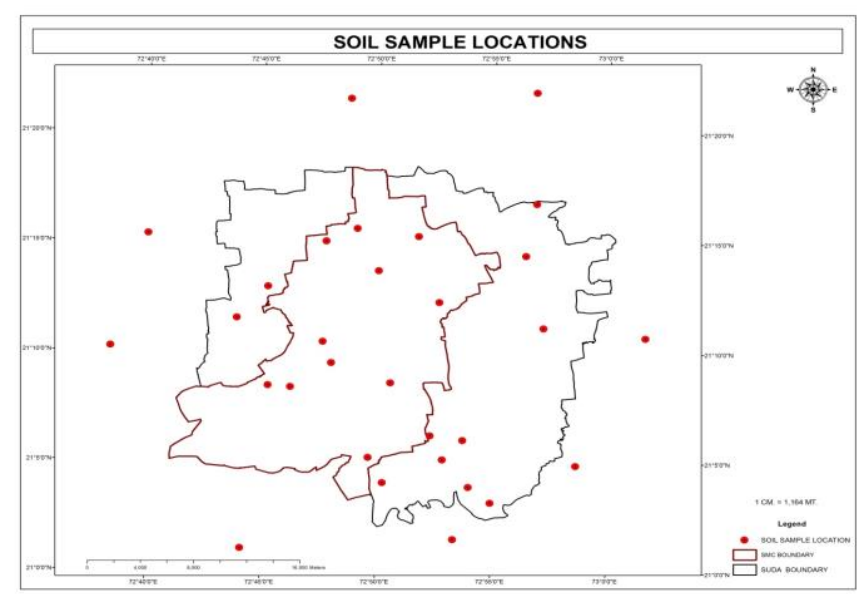

Figure 2 Digitized map of soil sample locations

\subsubsection{Weights of Parameters}

The AHP is used as a decision analysis device is a mathematical method developed by Saaty in 1977 for analyzing complex decisions involving many criteria. It is widely used by decision-makers and researchers as an MCE device. Pair wise comparison, which is applied within the scope of the AHP technique, provides a comparison of criteria which are used in decision analysis and determines values for each of these criteria. In AHP, a matrix is generated as a result of pair wise comparisons and criteria weights are reached as a result of these calculations. Also, it is possible to determine the consistency ratio (CR) of decisions in pair wise comparison. $C R$ reveals the random probability of values being obtained in a pair wise comparison matrix.

Table 2 Weights calculated through AHP

\begin{tabular}{|c|c|}
\hline Parameters & Weights \\
\hline Soil permeability & 0.22 \\
\hline Soil density & 0.17 \\
\hline Atterberg limits & 0.15 \\
\hline Moisture content & 0.15 \\
\hline Specific gravity & 0.20 \\
\hline \multicolumn{2}{|c|}{ Consistency Index $-0.0819<0.1 \ldots \ldots$ O.K } \\
\hline
\end{tabular}

2.1.2. Thematic Map Preparation 
The primary research data sources included Surat's 1:50,000 scale topo sheets, which were used to prepare the base map for the study. Based on field studies and Google Earth maps, soil permeability, soil density, Atterberg limits, moisture content and real gravity were all prepared by digitization. The geotechnical map was created using ERDAS IMAGINE through the image analysis and classification of the $22.8 \mathrm{~m}$ resolution Indian Remote Sensing satellite IRS1D imagery of the Surat district. Subsequently, using standard procedures, the thematic maps of housing, sensitive sites and waste land were extracted from land use maps. Secondary data was obtained through ground truth and surveys carried out at the sites concerned. In the context of the well-known desktop GIS program, the digitization and analysis of the thematic maps was performed; Arc GIS Desktop 10.0.0.

Digital thematic maps were generated by employing the following procedures:

- Scan of the primary paper maps available.

- The scanned map is geo-referenced to earth coordinates.

- Digitization of the primary maps on the computer, thus creating the digital thematic maps, each characterizing the influencing factor for the choice of landfill site.

- Locating the GPS coordinates and inserting the latitude and longitude into the database.

- Conversion of the latitude and longitude data using the software into the point data.

- Add attribute data to the positions.

\section{Soil Permeability}

Permeability is characterized as the property of a porous material that allows water (or other fluids) to be filtered through its linked voids. Gravels are extremely permeable, while stiff clay is almost impermeable. High soil permeability allows high concentrations of leachate to penetrate and low permeability allows low penetration through it. There are 3 groups on this map, from the least suitable to the most suitable for landfills. In this map, the pink color (number 1) shows low landfill suitability, and the green color (number 3 ) shows high landfill suitability. For landfill purposes, the cyan color (number 2) is moderately suitable.

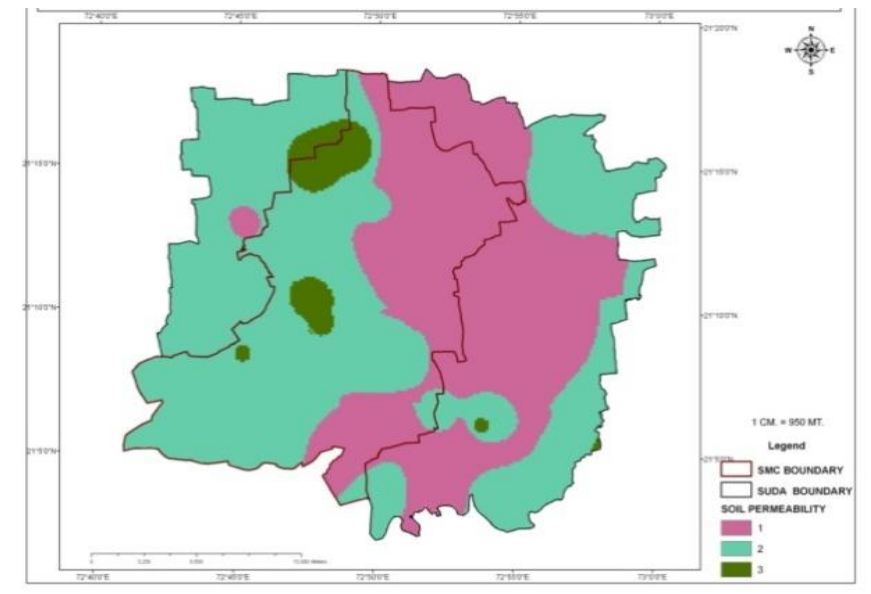

Figure 3 Soil permeability map

\section{Soil Density}

Density is expressed as the ratio of $\mathrm{M}$ to $\mathrm{V}$, as applied to any form of homogeneous mono-phase material of mass $\mathrm{M}$ and volume $\mathrm{V}$. This description leads to specific values under specified conditions that reflect a well-defined material property. However, applying this description will lead to different results for heterogeneous and multiphase materials, such as porous media, depending on the exact way the system's mass and volume are described. The map of soil density displays 1 to 3 soil density groups that indicate the least suitability, moderate suitability and most suitability, respectively. For land filling sites, high density is more fitting. Low soil density is classified as loose soil that allows further infiltration and is responsible for the pollution of ground water. 


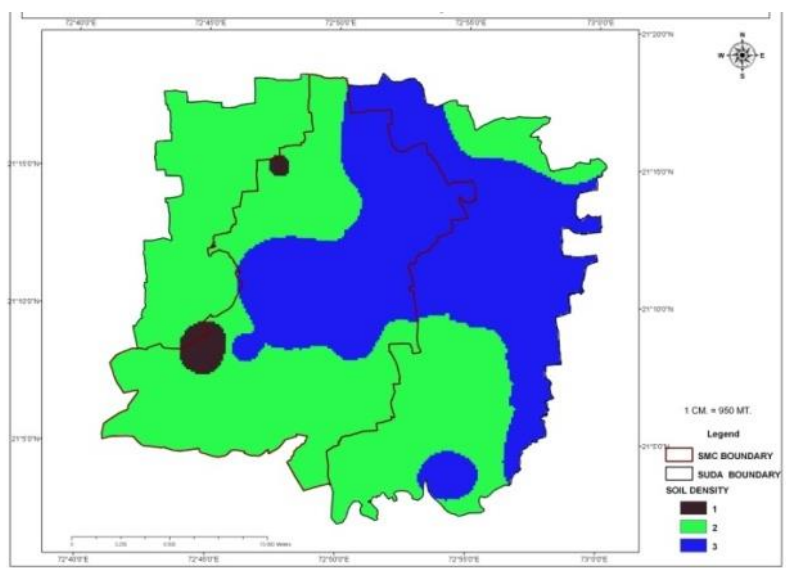

Figure 4 Soil density map

\section{Atterberg limits}

The Atterberg limits are a simple measure of a finegrained soil's essential water content: its shrinkage limit, plastic limit, and liquid limit. As a dry, artificial soil takes on growing quantities of water, it undergoes distinct behavioral and quality changes. It can appear in four states, depending on the water content of the soil: solid, semi-solid, plastic and liquid. The quality and behavior of a soil is distinct in each state and so are its engineering properties. Thus, based on a change in the behavior of the soil, the boundary between each state can be described. It is possible to use the Atterberg limits to differentiate between silt and clay and sand, and it can distinguish between different silts and clays. Values are 0 and 3 for the least acceptable to the most suitable for the operation of land filling. The green color is most appropriate for landfill in this map and the dark green and purple color is not suitable for landfill.

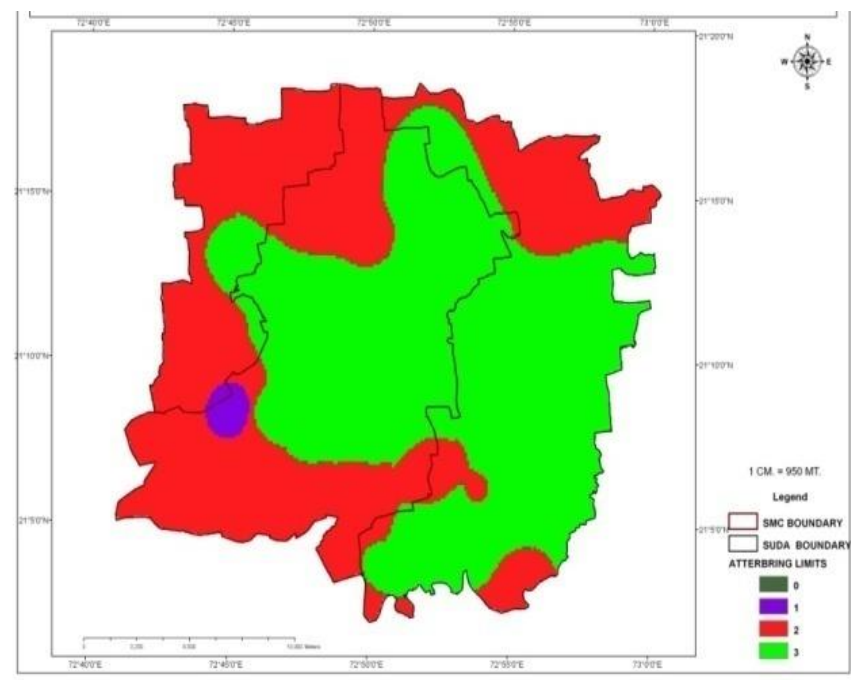

Figure 5 Atterberg limit map

\section{Moisture content}

One of the most critical parameters for soil quality is the moisture content of the soil. The amount of water found in a substance, such as soil (called muck), rock, ceramics, crops, or wood, is the water content or moisture content. The content of water is used in a wide variety of scientific and technological fields and is expressed as a ratio varying from 0 (completely dry) to the porosity value of the material at saturation. It can be given on a (gravimetric) basis of volumetric or mass. If the value of the moisture content is high, then the suitability of the landfill is lower or vice versa. Based on the actual field evidence observed, the brown color signifies landfill suitability and the green color is moderately suitable for landfill. The blue color in this map shows the most acceptable or optimal landfill position for soil point-of-view moisture content. 


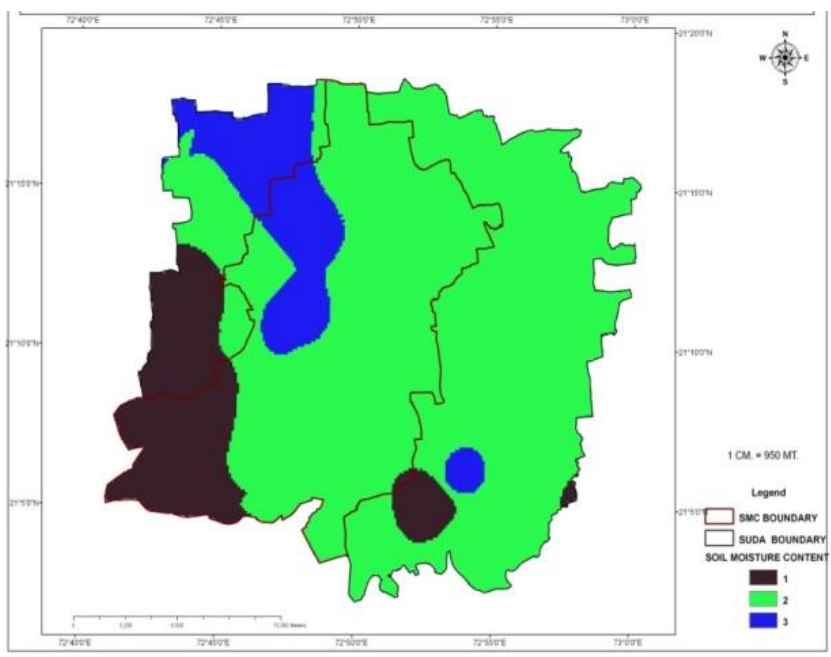

Figure 6 Moisture content map

\subsubsection{Specific Gravity}

It is the ratio between the density of the substance and the density of the reference substance, equivalent to the ratio between the mass of the substance and the mass of the reference substance and the volume of the substance. It is unsuitable for landfill purposes, reducing the importance of real gravity. A higher value is ideal for the development of landfill sites. In this map, there are three groups showing the least fitting to the most suitable. Cyan color indicates the least suitability and the highest suitability is seen in red color.

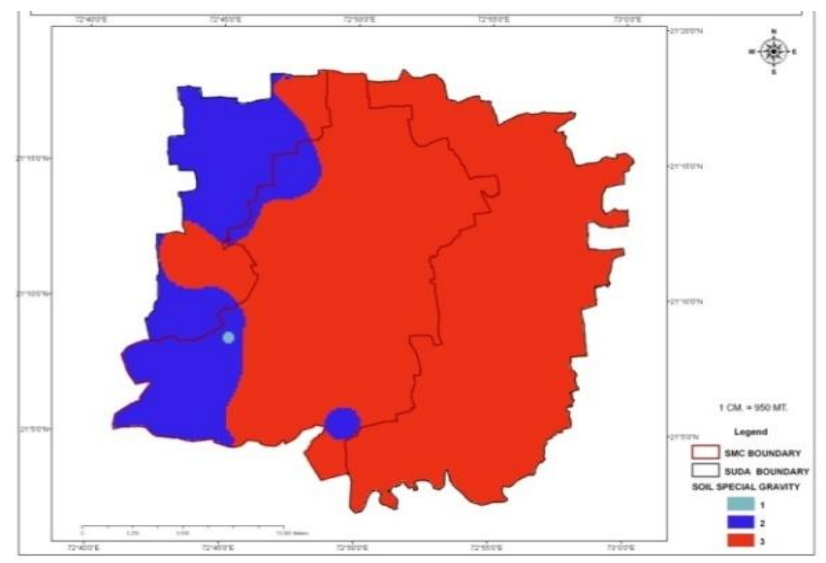

Figure 7 Specific gravity map

\section{Final suitability map}

Soil quality map is created on the basis of the combination of five soil parameters such as soil density, soil permeability, Atterberg limits, etc., the four and five number (green color) in this map shows most suiatble landfill position when only soil requirements for this form of research are taken into account. And number 1 indicates the least suitability for that. The key soil material in the magenta colored section is sand and gravel, so it is not ideal for land filling sites. In the map, the blue color shows 25-50 percent suitability, which is acceptable but avoided as per Table No 3. The red color is below $50-60 \%$, which is moderately acceptable, and the green color is below $60-70 \%$, which is ideal for landfill. In this map, the dark green color shows a highly suitable landfill location, which is below the 70-100 percent scale value.

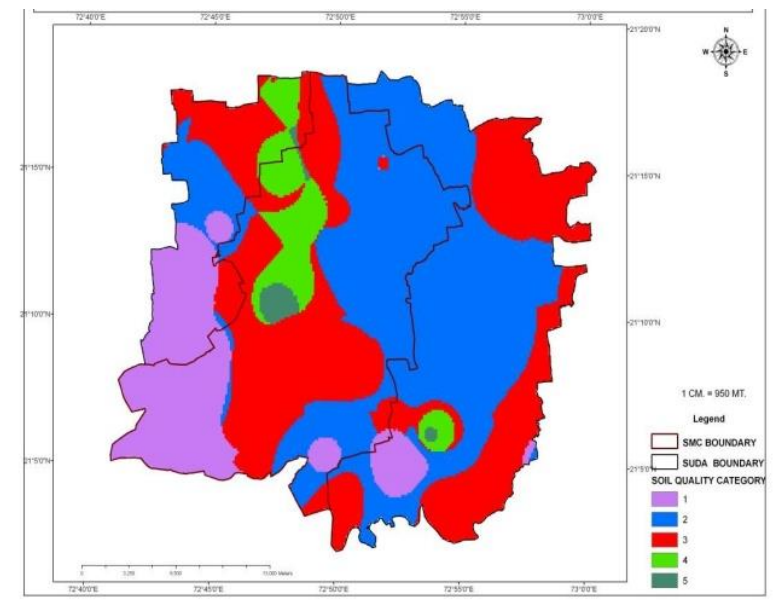

Figure 8 Suitability map

\section{CONSLUSION}

As a decision support method for landfill locations, GIS has been shown to be effective in identifying appropriate sites for landfill locations. GIS software was used in this study to identify landfill sites by generating maps according to the criteria set. A landfill siting process requires multiple parameters to be assessed and a great deal of spatial information processed. The following can be concluded after the study:

- The highest weight for this research is given to soil permeability by experts. It is also inferred that it is the most significant parameter for the development of landfills.

- It is noted that some portion of the north-east 
side of the study area is the most desirable place for landfill purposes. In this area, which is shown in dark and light green colors, is Saniya Hemad village.

- Also listed as suitable locations are Majura, Jahangirpura, Kosad and Variav. It is the northern part of the region under analysis.

\section{CONCLUSION}

Authorization enables to associate active packets with accountable heads, where principals work with the subjects that request the functions, e.g., an individual, a company, a provider, as well as a network supervisor. Virtual, any leader could be related to personal public/private secrets and electronically indications packages to make sure the correct id of their responsible group. The verification procedure securely validates the correspondence between critical identities and secrets. This paper provided a study on cryptographic principles and cryptographic models.

\section{REFERENCES}

[1]. GH. R. Dini, M. Amini, P. Zieaean Firooz Abadi, Seid Ramezan Mousavi, "GIS-Based Site Selection for Solid Waste Landfill Using Fuzzy Logic Case Study: Sari City, Iran”, Queensland Spatial Conference, (2008).

[2]. S.M. Issa \& B.A.L Shehhi, "A GIS-Based MultiCriteria Evaluation System for Selection of Landfill Sites: A Case Study from Abu Dhabi, United Arab Emirates", International Archives of the Photogrammetry, Remote Sensing and Spatial Information Sciences, (2012).

[3]. Zeinhom El Alfy \& Rasha Elhadary, "Integrating GIS with MCDM to Deal with Landfill Site Selection", International Journal of Engineering \& Technology IJET-IJENS Vol:10 No:06, (2010).

[4]. A.Karkazi,T.Hatzichristos,A. Mavropoulos, B. Emmanouilidou, Ahmed Elseoud, "Landfill
Siting using GIS \& Fuzzy Logic", Springer Publications, (2011).

[5]. Abdolhadi Nazari , Mohammad Mehdi Salarirad, Abbas Aghajani Bazzazi, "Landfill Site Selection by Decision-Making Tools Based on Fuzzy Multi-Attribute Decision-Making Method", Springer Publications, (2011).

[6]. V. Akbari, M.A. Rajabi, Chavoshi, Shams, "Landfill Site Selection by Combining GIS and Fuzzy Multi Criteria Decision Analysis, Case Study: Bandar Abbas, Iran", World Applied Sciences Journal 3 (Supple 1):pp. 39-47, (2008).

[7]. Mahnaz Eskandari \& Mehdi Homaee, "An integrated multi criteria approach for landfill siting in a conflicting environmental, economic and socio-cultural area", Elsevier Journal, (2012).

[8]. André L. O. Melo, Maria Lúcia Calijuri, Shahla Mahmodi, "Strategic Decision Analysis for Selection of Landfill Sites", Journal of Survey Engg, ASCE (2006).

\section{Cite this Article}

Dr. Digant Pastagia, Dr. Kamal Padhiyar, " GIS Site Selection Model for Sanitary Landfill Based on Geotechnical Parameters, International Journal of Scientific Research in Science, Engineering and Technology(IJSRSET), Print ISSN : 2395-1990, Online ISSN : 2394-4099, Volume 4, Issue 11, pp.297-303, November-December-2018. Available at doi $\quad:$ https://doi.org/10.32628/IJSRSET21841140 Journal URL : https://ijsrset.com/IJSRSET21841140 